\title{
Using brochure as a media in teaching reading descriptive text among the eight grade students of SMPN 1 Jiwan
}

\author{
Laelly Kartikasari $^{1}$, Nuri Ati Ningsih ${ }^{1}$, Fitra Pinandhita ${ }^{1}$ \\ ${ }^{1}$ Department of English Teaching, Universitas PGRI Madiun, Indonesia
}

\section{Article Info \\ Article history: \\ Keywords: \\ Reading \\ Brochure \\ Descriptive text}

Received January 13, 2018

Revised March 18, 2018

Accepted Mei 27, 2018

\begin{abstract}
The objectives of this research are: 1) to know how is the implementation of Brochure to teach reading for the eight grade students of SMPN 1 Jiwan, 2) to find out the advantages of the implementation of brochure to teach reading for the eight grade students of SMPN 1 Jiwan, 3) to find out the disadvantages of teaching reading descriptive text to the eight grade students of SMP N 1 Jiwan in schoooling year of 2016/2017. The research approach and type of this research is descriptive qualitative research. This research was held on SMP N 1 Jiwan, focus on the eight grade students. The source of data of this research are social situation, participant and document. The participant of this research are the students of class VIII G. In this research, the researcher as observer in the class. To get the data, the researcher uses observation, interview, and documentation. The technique of data analysis that used in this research are data condensation, data display, and drawing or verifying conclusion. The result of the research are 1) the implementation of Brochure as a media to teach reading divided into three stages, they are (a) pre- activities included greeting, checking students' attendance, and build background knowledge, (b) whilst activities included giving the explanation about the materials, and the implementation of brochure as a media, (c) post activities included review the materials, asking the students difficulties, gives a conclusion, and closing. 2) the advantages and disadvantages of the implementation of brochure as a media. The advantages are to increase the students interesting in following teaching reading, this media can helps the students to finish their task to answer all the questions, and to makes the students do not feel bored in teaching reading process. While, the disadvantages by using brochure that are some students still passive during teaching reading process, the students have less vocabularies make the students feel difficult to translate the meaning of the text. Based on the research, the researcher gives some suggestion. The teacher is suggested to use this media especially in teaching reading descriptive text. The students should increase their vocabulary in order to makes the students be easier to understand the meaning of the text. The future researcher are suggest to conduct other research in english teaching especially for teaching reading.
\end{abstract}

Copyright $(02018$ Department of English Teaching. All rights reserved.

\footnotetext{
Corresponding Author:

Laelly Kartikasari,

Department of English Teaching,

Universitas PGRI Madiun,

Jalan Setiabudi No.85 Madiun, Eas Java, Indonesia.

Email: laellykartika@gmail.com
}

\section{INTRODUCTION}

Reading is an activity of getting information. No one can get much information without reading. It must be mastered well by the students. Reading skill should be thought earlier to the children bacause it needs process to get the information from the text well. According to Nunan (2003: 68) reading is a kind of process where the reader combines some information of a text with their experience to build a meaning or new 
knowledge. It means that reading is an activity where people or learners comprehend about what they read and predicting the meaning based on their previous experience on knowledge.

Based on the observation conducted in the field at eight grade of SMPN I Jiwan, the fact in class shows that the students had problems and difficulties in understanding the meaning of English text. It can be identified by several indicators in the class related with their reading activity such as; 1) The student, who get difficulties in understanding the meaning of English text. 2) The teacher often uses monotonous activity in the teaching learning process. It caused the teacher do not use the interesting media because they still use conventional way. Thus, the teacher just asks the students to read certain text in the book or workbook. These activities make the students feel bored in reading class.

To overcome the problems above, the teacher needs to find and use appropriate media to help the students in teaching writing. Media are the means for transmitting or delivering messages. In the teaching learning perspective, media are used to deliver content to the learners for achieving effective instruction (Naz, 2010:1). In this case, the use of media in the teaching and learning process is needed to attract the students' attention and to make teaching learning activities more interesting and effective.

The suitable media that can be applied in teaching reading is visual media. Smaldiono (2005: 9) states that visual media are highly used to promote learning. They include diagram on poster, drawing on chalkboard, photograph or picture, graphic in book, cartoon and so on. It means that visual media can help to increase the learning process and make the students easy to follow teaching and learning process.

Based on phenomenon above, the researcher is interested in conducting a research entitled " $U$ sing Brochure as a Media in Teaching Reading Descriptive Text among the Eight Grade Students of SMPN 1 Jiwan. The purpose of this article is to know the interesting of the students' ability in reading descriptive text is increased by using Brochure at SMPN 1 Jiwan.

\section{METHOD}

This research uses qualitative research as the research approach because the researcher uses the phenomena that happen in a class as the data to be analyzed. While, the researcher also uses descriptive research the research type to analyze the data and give details description about the implementation of Brochure in the teaching and learning process. There are two participants in this research they are English teacher and students VIII G class of SMPN I Jiwan. In this research, the researcher uses methodological triangulation as the technique of collecting data. Methodological triangulation is a strategy which uses more than one method to get data such as observation, interview, and documentation. Thus, the researcher used triangulation method to measure the validity of the data in the research by observation, interview, and documentation in collecting the data. Therefore, to get the valid data in the research the researcher must compare the data result which is got from observation, interview, and documentation. In observation, the researcher observes the teacher and the students' activities of using Brochure at the eight G grade students of SMPN I Jiwan during the teaching learning process. While, in interview the researcher interviews English teacher and five students of G class of SMPN I Jiwan. Meanwhile, in documentation the researcher uses some documents such as syllabus, RPP (lesson plan), students' attendance work, students' readingwork, students' score, photograph, and checklist of observation.

English Teaching Journal, Vol. 6, No. 1, June 2018: $11-17$ 
In technique of data analysis, there are three steps of data analysis which is used by the researcher they are: data condensation, data display, and drawing or verifying conclusion. First is data condensation, in this step the researcher selects the entire data that have been collected from the observation, interview and documentation of VIII G class in the implementation of Brochure in teaching reading descriptive text for the eight grade students of SMPN I Jiwan in the schooling years of 2016/2017. It is used to get appropriate data to make the data easy and understand by the researcher. The data which are not useful should be deleted. The researcher only uses the data related to the research problem of the study. So, the data which are not useful must be deleted. It makes the researcher focus with the problem of the study.

Second is data display, in this step the data which has been selected and focused are based on the problem statements in the data reduction then will be displayed in the description form. Therefore, the researcher will make narration which explains of three problem of the study of the implementation of Brochure in teaching reading descriptive text for the eight grade students of SMPN I Jiwan in the schooling years of 2016/2017.

Third is drawing and verifying or conclusion, in this step the researcher makes conclusion and verifies the data to answer the problem statements in the research. The conclusions of the description are taken after the researcher presented the data. The researcher reviews the finding of the research to give clear explanation of the aspect that the researcher's analysis in mainly about. Then, the research findings will be verified by using triangulation in order to measure the validity of the data of the research findings.

\section{RESULTS AND DISCUSSION}

In this part, the researcher presents the result findings about teaching reading descriptive text by using Brochure for the eight grade students of SMPN I Jiwan. The researcher gets the research findings in the implementation of Brochure in teaching reading descriptive text for the eight grade students of SMPN I Jiwan in the schooling years of 2016/2017. The implementation of Brochure is divided into two steps. First is preparation steps. In this steps, the teacher must prepares the instrument of the research that needed by the teacher in the learning process such as lesson plan (RPP), syllabus, the material, and checklist of observation are prepared before the teaching and learning process done. Second is teaching learning process. In the teaching and learning process consists of three steps. In the pre-activities, the teacher gives some kind of opening before go to the teaching and learning process. These activities include greeting the students, asking the students' condition, praying together, checking students' attendance, and explaining the purpose of the study to the students. While, In the whilst activities is the main activity in the teaching and learning process. The teacher give stimulate to introduce the materials and the implementation of teaching reading descriptive text by using Brochure. Meanwhile, In the post activities the teacher gives the end section or conclusions to the students in the teaching and learning process.

There are some advantages in the implementation of Brochure in teaching reading descriptive text, they are: 1) brochure media increase the students interesting in following teaching reading process, 2) brochure media can help the students to finish their task to answer all the questions, 3) brochure media makes the students do not feel bored in teaching reading process.

The researcher gets the research findings about the disadvantages in the implementation of Brochure in teaching reading descriptive text for the eight grade students of SMPN I Jiwan. There are some 
disadvantages in the implementation of Brochure in teaching reading descriptive text, they are: 1) students are still passive during teaching reading process and 2) students have less vocabularies make the students feel difficult to translate the meaning of the text.

In this part, the researcher discusses the result of the research based on the three problems of the study which has been formulated in the previous chapter. There are three problems of the study in this research, they are drawn as follows:

In this research, the researcher discusses the result of observation, interview, and documentation of the implementation of of Brochure in teaching reading Descriptive text for the eight grade students of SMPN 1 Jiwan. There are two activities in this part. They are preparation and teaching and learning process. Those are described as follows:

a. Preparation Step

Preparation is the beginning activity that is done by the researcher before doing teaching and learning process in the classroom. First, the teacher must prepare syllabus then arrange lesson plan or RPP. After that, the teachermakes checklist of observation. Next, the teacher prepares the material that is used in teaching readinjg dexcriptive text. Besides, the teacher also prepare printed of Brochure to support the teaching and learning process.

b. Teaching and Learning Process

Teaching and learning process are the activities that are done by the teacher to teach the students in the classroom. In the implementation of Brochure in teaching reading descriptive text, the teaching and learning process divided into three steps. They are pre activities, whilst activities, and post activities. Those are described as follows:

1) Pre-Activities

The pre activities are the first activity in the teaching and learning process which has some activities done by the teacher and the students before the lesson begin. In the implementation of Brochure teaching reading descriptive text for the eight grade students of SMPN 1 Jiwan in the schooling year of 2016/2017 appropriate with the lesson plan or RPP and checklist of observation. There are five activities in the pre activities found based on the lesson plan or RPP and checklist of observation. They are greeting, asking the students' condition, praying together, checking the absent, and explaining the purpose of the study.

\section{2) Whilst-Activities}

Whilst activities are the second and main activity in the teaching and learning process has been done by the teacher. In the implementation of Brochure in teaching reading descriptive text for the eight grade students of SMPN 1 Jiwan in the schooling year of 2016/2017 appropriate with the lesson plan or RPP, checklist of observation, and the previous research in Chapter II. According to Alizen (2016) They are teaching procedures of using Brochure by Alizen (2016) they are as follows:

1. The teacher introduces the material about descriptive text.

2. The teacher gives the students example of descriptive text.

3. The teacher asks the students to identify the generic structure of descriptive text.

4. The teacher gives the students brochure of Holiday Package.

5. The teacher asks questions to the students about Holiday Package brochure. 
6. The teacher asks the students to describe the facilities and benefits of Holiday Package brochure.

7. The teacher reviews the previous material

8. The teacher gives the students about English Competition brochure

9. Asking questions to the students about English Competition brochure.

10. The teacher asks students to describe it.

11. The teacher asks the students about descriptive text.

Based on the activities above, it can be concluded that the whilst activities of the implementation of Brochure in teaching reading descriptive text for the eigtht grades students of SMPN 1 Jiwam in the schooling year of 2016/2017. is suitable with lesson plan or RPP and checklist of observation. Then, there are some activities which are same between the research and previous research by Alizen (2016) such as introduces the material about descriptive text, gives the students example of descriptive text, asks the students to identify the generic structure of descriptive text, gives the other brochure the students

1) Post-Activities

The post activities are the last activity in the teaching and learning process. In the implementation of Brochure in teaching reading descriptive text for the eight grade students of SMPN 1 Jiwan in the schooling year of 2016/2017 appropriate with the lesson plan or RPP and checklist of observation. There are four activities in the post activities found based on the lesson plan or RPP and checklist of observation. They are the teacher asks some question related to the materials which have learned, the teacher asks the students' difficulties about the lesson, the teacher makes summary about the lesson together, the teacher closes the lesson with greeting and praying together.

Based on the explanation above, it can be concluded that there are two activities in the implementation of teaching reading descriptive text by using Brochure for the eight grade students of SMPN 1 Jiwan in the schooling year of 2016/2017. They are preparation and teaching and learning process. In the preparation, the researcher prepares syllabus, lesson plan or RPP, checklist of observation, material, and printed of Brochure. While in the teaching and learning process consists of three steps. They are pre activities, whilst activities, and post activities. Based on the observation, those activities are suitable with lesson plan or RPP, checklist of observation, and previous research of teaching reading using Brochure by Alizen (2016) in Chapter II although the teacher changes, adds, and throws some activities in it.

The researcher wants to discuss about the advantages on the use Brochure as a media to teach reading descriptive text to the eight grade of SMP N 1 Jiwan in schooling year of 2016/2017. The advantages of brochure as a media to teach reading are described as follows:

a. Brochure as a media increase the students interesting in following teaching reading process.

By using Brochure as a media to teach reading descriptive text is the media can make the students interesting to follow the teaching reading process. It can be seen from the observation when the teacher shows the brochure to the students. They pay attention to the teacher.

From the documents of photographs, it shows that the students participate during the teaching reading process on the use of Brochure. Some students raise their hand to give their opinion about the teachers' question. Students also doing the task related with the question given. The observation checklist also shows that the students follow all the activities during teaching reading process. It means that the

Using brochure as a media in teaching reading descriptive text... (Laelly Kartikasari) 
students interest to follow all the activities during teaching learning process by using Brochure in teaching reading.

During teaching reading process on the use of Brochure as a media make the students of VIII G become interest to follow the lesson. In this activity the students more active and they feel enjoy in the class. it happens because of some factors, such as the students' interest in learning process, the students pay attention to the teacher while the teacher explain the materials, students active in doing asking and answering the questions.

b. Brochure media can help the students to finish their task to answer all the questions.

The advantages from the use of Brochure as a media to teach reading descriptive text is this media can help the students to finish their task. It can be seen from the observation when the teacher gives the worksheet or individual tasks for the students to answer the questions. The students are helped to focus in reading the text.

The implementation of brochure is effective for the students. It is shown from the activity the students more active to answer the questions. They are also enthusiastic to answer all the questions. Based on the verification of data, it can be found that the students are helped to complete the question related with the descriptive text.

c. Brochure media makes the students do not feel bored in teaching reading process.

By using this media, the students do not feel bored in teaching reading process, because of those, the teacher gives the different media to teach reading. Based on the analysis above, it can be concluded that the researcher finds the advantages of the implementation of Brochure as a media to teach reading descriptive text to the eight grade students of SMP N 1 Jiwan. The students are interesting in following teaching reading process, this media can help the students to finish their task to answer all the questions, and Brochure makes the students do not feel bored in teaching reading process.

In this part, the researcher explains the disadvantages of on the use of Brochure as a media to teach reading descriptive text to the eight grade students of SMP N 1 Jiwan. The advantages are explained as follows:

a. Students are still passive during teaching reading process

The disadvantages of the use of Brochure as a media to teach reading descriptive text is some students are still passive during teaching reading process. During the observation there are some students who are not active in teaching learning process only there are some students who are active and participate to teaching reading process. The students are not active, they are busy with themselves they are playing smartphones and also there are some students who are talking with their friends. It makes the class is not conducive and comfortable. They are passive and not active during teaching reading process.

b. Students have less vocabularies make the students feel difficult to translate the meaning of the text

The second disadvantages of the use of Brochure as a media to teach reading descriptive text there some students have less vocabularies and make the students feel difficult to translate the meaning of the text. It can be shown during the observation, some of the students are confused to answer the question that are the teacher helps them to give the correct meaning. 


\section{CONCLUSION}

Based on the discussion above, the researcher takes the conclusion that Brochure is one of media that can be used to make the students easily to understand the meaning of English Text. There are two activities in the implementation of teaching Brochure in teaching reading descriptive text for the eight grade students of SMPN 1 Jiwan in the schooling year of 2016/2017. They are preparation and teaching and learning process. In the preparation, the researcher prepares syllabus, lesson plan or RPP, checklist of observation, material, and printed of Brochure While in the teaching and learning process consists of three steps. They are preactivities, whilst-activities, and post-activities. In pre-activities consists of some kind of opening before go to the teaching and learning process. These activities include greeting the students, asking the students' condition, praying together, checking students' attendance, and explaining the purpose of the study to the students. In whilst-activities the teacher explains the materials and the implementation of Brochure in teaching reading descriptive text. In the post activities, the teacher gives the review and conclusion the material to the students in the teaching and learning process. Those activities are suitable with lesson plan or RPP, checklist of observation, and previous research by Alizen (2016) in Chapter II although the the teacher changes, adds, and throws some activities in it.

There are some advantages in the implementation of Brochure in teaching reading descriptive text for the eight grade students of SMPN 1 Jiwan in the schooling year of 2016/2017. First is Brochure media increase the students interesting in following teaching reading process. Second is Brochure media can help the students to finish their task to answer all the questions. Third is Brochure media makes the students do not feel bored in teaching reading process. Besides there are some advantages, also find some disadvantages in the implementation of Brochure in teaching reading descriptive text for the eight grade students of SMPN 1 Jiwan in the schooling year of 2016/2017. First is students are still passive during teaching reading process. Second is students have less vocabularies make the students feel difficult to translate the meaning of the text.

\section{REFERENCES}

Alizen, G. H. (2016). The Effectiveness of Brochure Toward Students' Reading Comprehension Skill in Descriptive Text of Eight Grade Students at SMPN 2 Sumbergempol. Tulungagung: English Education Department Faculty of Tarbiyah and Teacher Training State Islamic Institute (IAIN) of Tulungagung.

Bogdan and Biklen. (2007). Qualitative Research Methods for the Social Sciences. Bostom: Pearson Education.

Miles, et al. (2014). Qualitative Data Analysis: A Methods Sourcebook. $3^{\text {th }}$ Edition. United States of America: Sage Publications, Inc.

Nunan, D. (2003). Practical English Language Teaching. New York: The McGraw Hill.

Smaldino, Sharon, Russel \& Molenda, M. (2005). Instructional Technology and Media for Learning. Pearson: Merrill Prentice Hall.

Wahyuni, Sari. (2012). Qualitative Research Method: Theory and Practice. Jakarta: Salemba Empat. 